\title{
The influence of geopolitical events on tourism in Egypt
}

\author{
Florentina-Stefania NEAGU \\ The Bucharest University of Economic Studies, Bucharest, Romania \\ stefanianeagu15@gmail.com
}

\begin{abstract}
The political, military, terrorist acts that took place during 2011-2017 have affected the tourism industry to a large extent, their effects being seen in the gradual decrease of the number of tourists generating income not only for tourism agencies, but also for tourism objectives for small merchants selling their products near tourist attractions. This has led to the closure of several souvenir shops, but also to the reduction of revenue generated by the flow of tourists to hotels, guides, restaurants. The Egyptian government has attempted to relaunch tourism by contracting a loan from the International Monetary Fund, reopening tourist attractions such as King Seti and Queen Nefertari, the Antiquities Ministry is continuing to finance the acquisition of metal detectors and scanners that are located in the tourist attractions included in the patrimony national. On the other hand, the fiscal measures adopted by the government, which impose VAT on local goods and services, have led to a price increase for all products and ultimately affecting not only citizens but also tourists who find that prices for tourist packages have increased within a few months. To highlight how great the influence that geopolitical events have on Egyptian tourism, data were analyzed for the period 2011-2017 of the Central Agency for Public Mobilization and Statistics of Egypt, World Tourism Organization and the World Factbook..
\end{abstract}

Keywords: tourism, fiscal measure, security.

\section{Introduction}

In Egypt, tourism is one of the most important branches of the national economy with a total contribution of $7.2 \%$ of GDP for 2016 , the tourist attractions in this country attract tourists throughout the year. Here are several types of tourism, of which the most important is archaeological, due to the fact that Egypt holds about one third of the world's most famous historical monuments, including two of the 7 wonders of the world. Apart from Egypt's touristic tourism, several tourist attractions have been promoted, including recreational tourism, ecotourism, beach tourism, therapeutic tourism, sports tourism, maritime tourism, desert tourism, yachting tourism and festival tourism including cultural events, symposiums and tourist exhibitions.

A destination that attracts many tourists today is the Diving Center in Sharm elSheik, which in 2007 was awarded the title of World Diving World Destination. This city differs from other areas of Egypt in that it has a very diverse natural environment but at the same time it is also a resort where you can fish, you can practice diving in small and deep depths. Moreover, in the last few years the conference tourism has developed, mainly taking place in the capital of the country, summing up over 600 conferences and about 500 exhibitions and ceremonies over the last five years.

\section{Literature review}

After the events of the street in Tunisia in December 2011 and the start of the Arab Spring, Egypt was greatly affected, and this was also accentuated by the removal of President Hosni Mubarak. The effects of the revolution have been much stronger and have been sustained for many years, escalating with the accentuation of terrorist attacks to date.

The crime rate has doubled, criminality and violence have risen in the streets, with over 200 robberies being recorded in a few months, sexual violence against women 
has intensified, causing street movements to be accentuated. Other events that have occurred have kept the country for several months with partially disrupted activity, hospitals have no equipment, electricity has been interrupted, and fuel has been limited, generating bottlenecks in traffic and rising gasoline prices.

The economic effects of these events could be seen at the end of 2013, rising poverty levels, rising consumer goods prices and the unemployment rate reaching 13.2\% (Ryan \& Sarah , 2013). According to the Central Agency for Public Mobilization PICBE | 662 and Statistics, Egypt has begun to be affected by political upheaval, street movements since 2013, leading to the British Foreign Ministry's failure to advise Egypt as a holiday destination for its citizens. This was seen in the drop in the number of British tourists from $18.5 \%$ in 2010-2014. At the end of 2014, the Association of Tourism Agencies in the UK published the report on the tourism market, which showed that the popularity of a tourist destination is affected by political, social and economic disruption (Parkinson \& Heyden, 2015). In 2015, there was a slight increase in the number of tourists due to a global advertising campaign promoted by the Egyptian government for the recovery of the economy (Alsharif, 2015).

In 2016 there were large decreases in tourism revenue following the bombing of a Russian airline company with 224 people on board, the immediate effect of this attack was to discourage Russian citizens from traveling to Egypt. This event made 2016 revenues drop by half compared to 2015 , or 7.4 billion dollars to 3.8 billion dollars. In 2017, Egypt's economy was affected by several events with long-term impact on the country's development.

For the country's economic recovery, the Egyptian government is contracting a \$ 12 billion loan from the IMF in 2016 and a USD 1.15 billion loan from the World Bank by the end of 2017 (World Bank-Press release, 2017), in exchange for a strong economic reform that includes introducing a new value added taxes applied to all local goods and services (KPMG, 2017), energy subsidies and deregulation for certain industries, these measures have led to a fluctuation in the exchange rate coupled with the sharp devaluation of the Egyptian pound.

The Suez Canal has reduced customs duties as a result of the decline in maritime trade, but in the event of a terrorist attack on ships transiting the channel, the effects would be inconsistent with measures adopted by the government. According to the Central Agency for Public Mobilization and Statistics, Egyptian tourism registered a steady increase in the first three quarters of 2017 as shown in Figure 1. Most tourists visiting Egypt every year are Europeans, Arabs, Americans. Tourists come to visit tourist attractions, taste Egyptian cuisine, buy souvenirs from markets and bazaars, the Red Sea Riviera has several resorts where tourists can practice more sports but also have a place for entertainment and shopping. 


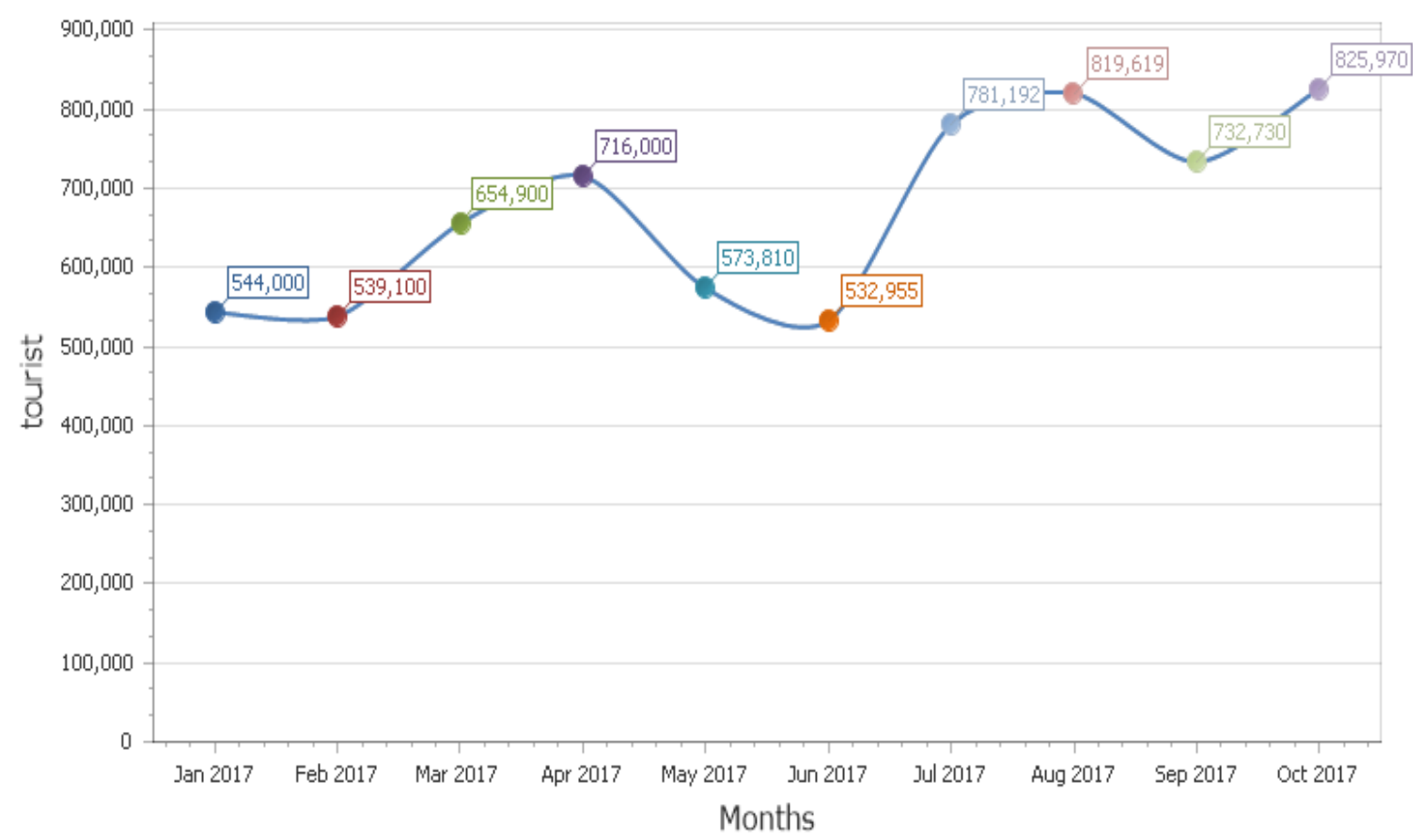

PICBE $\mid 663$

Figure 1. Number of tourists arrived in Egypt monthly

Source: (Central Agency for Public Mobilization and Statistics)

In view of the geopolitical events that took place in recent years, the Travelzoo Company, in collaboration with the Bournemouth University School of Tourism faculty, conducted a survey to measure travelers' perceptions of holiday safety and security, as well as key factors can influence the behavior of travel consumers (Morakabati, Fletcher, \& Beavis, 2017).

The results of the study have shown that tourists' concerns about producing a terrorist attack are far greater than the risks of epidemics, natural disasters and organized crime phenomena. Moreover, the instability of the security climate induces the fact that in the coming months the tourism industry and the governments of the countries most affected by terrorism and violent extremism provide clear information on the security of tourist destinations as well as travel agencies to provide relevant data on possible risks for a certain area before tourists reserve their stay.

On the other hand, a standardization system for the certification of the security of tourist areas has to be implemented at international level, so tourists would benefit from a high level of trust in the tour operators but also in the destinations they are traveling to. Addressing the current climate of global insecurity needs to be addressed by developing a better communication with consumers about the risk they may encounter in some countries.

As can be seen in Figure 2, tourists perceive more states as the most dangerous in the world, with countries that have been affected by attacks in the past two years with many deaths and where they have had violence in the street, including Egypt, which in 2016 and 2017 had some major attacks on the mosques that produced hundreds of dead and wounded.

This high level of perception is also influenced by the media that, immediately after a terrorist attack, broadcasts pictures and witness reports in news breaking news, which is a means of informing tourists who want to go on a trip. 


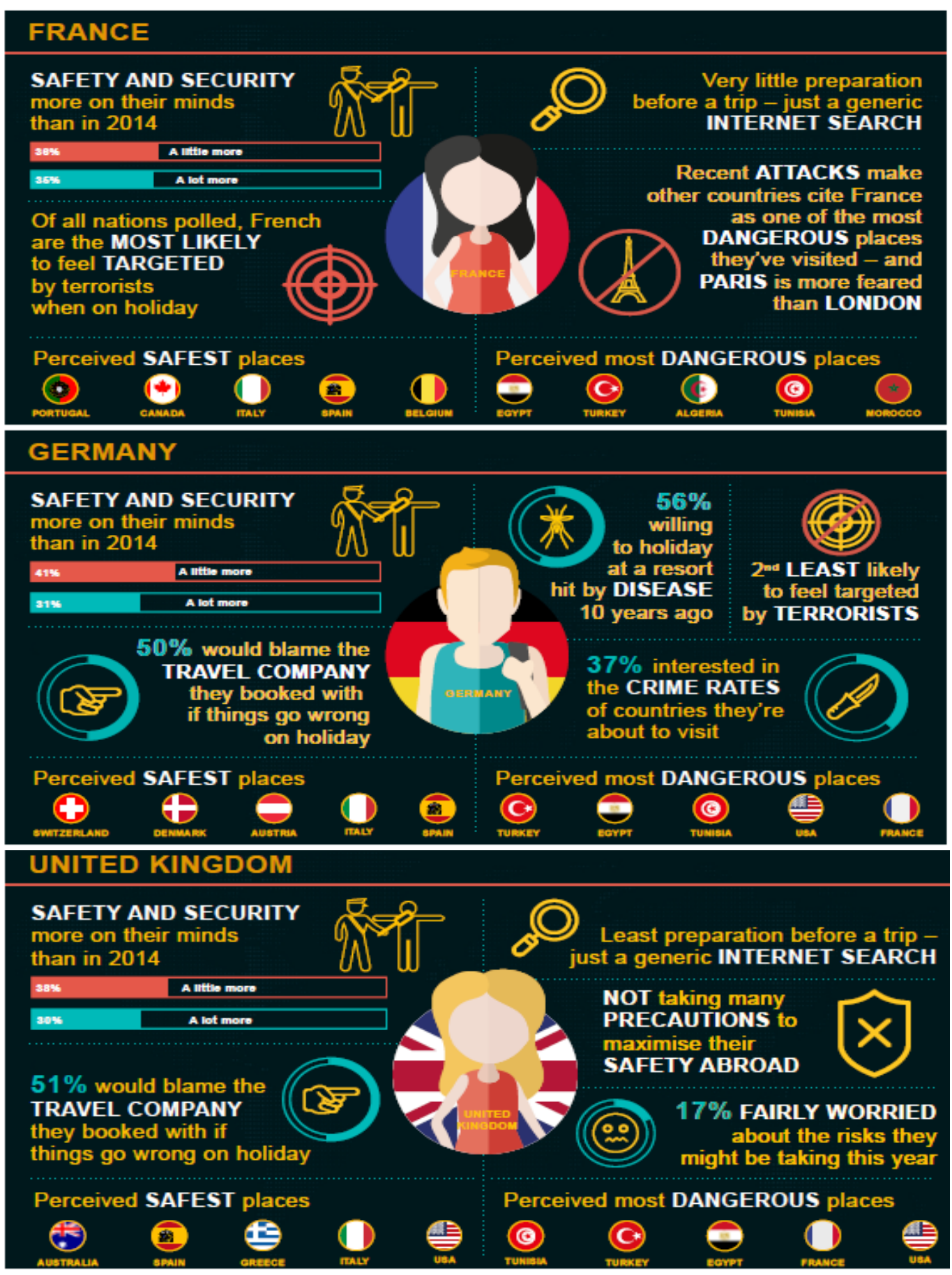

Figure 2. Consumer perceptions of some tourist destinations

Source: (Morakabati, Fletcher, \& Beavis, 2017, pp. 12-13)

If the tourists use only mass-media as a means of informing themselves and from other sources, they may find themselves in a position to postpone or cancel the trip (Rittichainuwat \& Chakraborty, 2009, p. 412).

\section{Methodology}

In order to determine how great the influence of geopolitical events on the tourism industry is, but also the economic costs of terrorist attacks, the Annual Reports of the Global Terrorism Index, the Center for Strategic Studies and Country Reports on 
Terrorism of the Bureau of Counterterrorism, United States Department of State Publication.

Terrorist attacks cause very high costs to any state depending on the intensity of their production. The Global Terrorism Index for 2017 shows that about 94\% of terrorist attacks occur in the Middle East, North Africa, Sub-Saharan Africa and South Asia. Until now, the region's most secure in terms of terrorist attacks or extremist manifestations are Central America and the Caribbean.

Moreover, the report shows that $99 \%$ of all deaths in recent years are due to political instability or countries in conflict with its neighbors, or there is a high level of political terrorism in torturing detainees, extrajudicial killings and the arrest of suspects without to have a trial (Tahrir Institute for Middle East Policy, 2015, p. 3).

Egypt being an example of practicing such measures, in this sense Egyptian President Abdel Fattah el-Sisi, after being appointed to office in 2014, said the fight against terrorism is the top priority of his mandate. So, in order to justify constant aggression on the civilian population, in the name of fighting terrorism, thousands of citizens accused of political terrorism and members of the Muslim Brotherhood and activists who demand political liberties have been closed.

Terrorism has a major impact on the world economy, worth \$ 84 billion in 2016 (Global Terrorism Index, 2017, pp. 8-9), this value showing that terrorism has a much lower value than other major forms of violence that have been in the Arab States for decades.

The economic cost of terrorism does not reflect the indirect impact it has on the business environment, capital investment and the costs generated by security agencies to prevent and combat terrorism, but also to eradicate violent extremism. Moreover, terrorism is a category of violence where the cost of terrorist prevention operations exceeds the cost of producing a terrorist attack with a victim or a terrorist attack on a critical infrastructure.

Worldwide, there are four major terrorist groups that have produced the most terrorist attacks with victims but also the destruction of buildings, historical objectives, these groups are: Islamic State, Boko Haram, Al-Qaeda, and the Taliban. The highestachieving terrorist group is the Islamic State, which has recorded three times lower incomes in 2016 than in 2015, from \$ 81 million / month to \$ 16 million / month. The main sources of income of a terrorist group are: donations, money transfers, drugs and people trafficking, protection fees and income from the sale of artifacts, etc.

The countries of origin of those in Europe are mostly North African (Tunisian, Moroccan) and Middle East (Iraqi, Pakistani, Afghan). The novelty of the attacks by intelligence and counterterrorism specialists is the very low cost of an assault; the cause is the shift to simple attacks on civilians in highly populated areas. Attacks that have taken place in Europe over the past two years have been carried out at costs of less than $\$ 10,000$, which shows that attacks can be funded by the attackers' own resources without external funding.

In 2016, global attacks occurred as follows: 54\% bombings and explosions, $18 \%$ armed attacks, $17 \%$ hostage-taking, $6 \%$ attack on supply facilities and critical infrastructure (Global Terrorism Index, 2017, p. 19). Two large clusters and several unrelated groups operate in Egypt, the most active groups being the Islamic State Branch in Egypt and the Wilayat Sinai Group. In 2017, three quarters of the violence and assassinations occurred were caused by Daesh's two subsidiaries, totaling more than 200 attacks in the first three quarters of the year, almost three times more than in 2016 (Africa Center for Strategic Studies , 2017). 
Egypt also faced violent acts against Liwa al-Thawra's Abdel Fattah el-Sisi's regime and Harakat Sawa'd Misr (HASM), the two taking responsibility for the attacks in Egypt. Revolutionary punishment and popular resistance organizations have been less active than they have been in the past, and the presence of foreign fighters has not increased. The Egyptian Armed Forces (EAF) maintained the smuggling of smuggled goods through the tunnels used at the border between Egypt and Gaza, which led to a reduction in illegal activity through those tunnels.

In May 2018 the presidential election is scheduled, the current president announcing that he will no longer run as the constitution of the country allows only two consecutive four-year terms, but all the opponents were eliminated, the last of them announcing their withdrawal from the presidential race at the end of January 2018 This shows that Egypt is increasingly moving away from a democracy that tends to dictatorship.

Despite all these slippages, Egypt is an element of stability in the region, allowing it to play an important role in North Africa and the Middle East in the fight against terrorism and maintaining close ties with both European states and the US. Egypt together with its allies imposed an embargo on Qatar and also contributed to the political reconciliation between the Hamas group and the Palestinian National Authority

The strongest attack took place in November 2017, when the Islamic State Party provoked an explosion in a mosque in northern Sinai, and then the assailants opened fire on the civilians who were in weekly prayer, the assassination made 305 dead and 128 injured ( Walsh \& Youssef, 2017).

Another attack took place a month ago when the Islamic State-affiliated Wilayat Sinai group robbed a bank robbing 17 million Egyptian pounds equivalent to $\$ 1$ million and killing eight people after the robbery, the cause of this robbery is given that the group faces a financial crisis after being constantly attacked in Syria and that Iraq remains without financial resources unable to meet the needs of its fighters.

The success of this robbery will most likely lead to the intensification of robberies over other parts of the country, but also to other objectives that have a lot of cash in the cashier, such as currency exchange offices, jewelery, government money transport vehicles or transport of high value goods between two cities. Although the bank benefits from a high level of security, it is near a security area that is monitored on a permanent basis for monitoring to prevent civilians from accessing the area. The success of the operation was based on intelligence gathering and very good training, the working groups of the terrorist group resemble those of intelligence services and national armies.

In order to prevent terrorist attacks, the Egyptian government has implemented two anti-terrorism laws that were ratified in 2016 by Parliament and which require the establishment of a mechanism for identifying terrorist groups and terrorists in the country or those who want to come to Egypt. The second law increases the sanctions on planning and committing terrorist attacks (Country Reports on Terrorism, 2016, p. 181), and the novelty that this law brings is that the news trusts and journalists who publish false news or information in disagreement with the official reports of the Egyptian government receive a fine equal to the average annual salary of local journalists.

However, in order to combat terrorist attacks, it is necessary to end the financing of terrorist groups, and to this end Egypt wants to solve this problem which greatly affects the economy of the country, but also to align with the international standards regarding the legal framework on terrorist organizations. In order to implement these standards, the government has set up a terrorist financing prevention system and has 
also instituted a number of procedures to implement the terrorist offenses committed by the Daesh and Al-Qaeda groups.

All these measures are also due to the fact that Egypt is a member of the Regional Financial Action Task Force for the Middle East and North Africa as well as of the Counter-ISIS Coalition. A vulnerability to Egypt's security and economy is represented by transactions and cash payments for which no identity card is presented; moreover, a large proportion of the population does not have a bank account, and this can also facilitate the financing of terrorism. To mitigate these effects, the government has proposed to implement several measures such as digitalisation of taxes that citizens pay to the state, diversify the range of banking services, and create more mobile applications for payments (Egypt Risk\&Compliance Report, September 2017, p. 14).

The organized crime phenomenon is present in Egypt and is in direct connection with terrorist organizations. In this respect, the Fund for Peace reports annually in which it calculates the Fragile State Index, this index shows which are the most common attributes that can create vulnerabilities for a state, the most common attributes among states affected by terrorism and organized crime are the loss of physical and political control over a part of the territory, the use of illegitimate force in some cases, the failure of the government to provide the necessary infrastructure and infrastructure-related public services, etc. The Fragil State Index calculation is based on four general indicators and 12 specific indicators, which indicate the factors that can influence the country's development such as: high levels of corruption, criminal behavior by officials, state incapacity to collect taxes and taxes to citizens, inequalities between social classes, population decline or growth as well as events such as revolutions, protests, long-term strikes ( Messner \& et al., 2017, p. 7).

In order to diminish these factors, the political power needs to apply measures that focus on creating a strong institutional capacity, focusing primarily on five vital institutions of any country, namely executive leadership, justice, police, army and public services. It is also necessary that the measures adopted be monitored on a permanent basis and evaluated. The Fragil State Index was calculated for 178 states, and Egypt is ranked 36th with a high level of warning, which is due to all of the above. According to the Bureau for International Narcotics and Law Enforcement Affairs, the main illegal proceeds are smuggled with antiquities, arms trafficking, and drug trafficking, and some terrorist groups have turned to fraud using the new technologies and social networks (International Narcotics Control Strategy Report, 2017, p. 82).

One problem facing Egypt is respect for human rights and human trafficking, although the government is making considerable efforts that trafficking decrease, Egypt remains a country of transit and destination for children, women and men use to work heavy. Egyptian women from disorganized families or from very poor areas often come in the hands of traffickers selling or renting them for sex trafficking, forced labor under conditions unfit for people in countries such as Kuwait, the United Arab Emirates, Saudi Arabia or to rich people in Egypt. Moreover, in the major cities of the country such as Cairo, Luxor, Alexandria, sex tourism is practiced with minors, and most of the time children are pushed to these networks by parents who receive material benefits from them (Egypt Risk\&Compliance Report, September 2017, p. 11).

In the category of vulnerable people who are subject to many degrading work such as begging, work on sites up to exhaustion are also foreign workers coming from countries like Ethiopia, Philippines, Sri Lanka, Bangladesh who left their countries to earn their living in Egypt. In a similar situation there are also refugees from conflict areas such as Syria, Middle East and Horn of Africa, as well as asylum seekers from Sub- 
Saharan African countries and the Horn of Africa heading to European countries are likely to become victims of these networks. However, over the past two years, much of the organized crime group has left the northern area of Egypt south to the border with Libya and Sudan

\section{Results and discussion}

It can be noticed that in countries where there is a long-term conflict, such as Egypt where social instability and the existence of terrorist groups strongly affect tourism industry and related activities.

After the 2011 revolution, the Egyptian government and tourism ministry tried to promote a modest marketing campaign to attract tourists to the Sharm el-Sheik area, and considerable financial resources were also allocated to protect tourist hotspots.

Over the past three years, the tourism ministry has proposed several measures for the development of the tourism industry, including:

a) introducing into the national strategy a point that promotes tourism by an advertising company at international events, maintaining and increasing the country's competitive status on the receiving markets of tourists such as Germany, France, Italy and attracting tourists from countries such as Russia and the UK;

b) expanding to the new markets in India and China, but also to 26 other South European and Latin American markets, as well as improving the image of the destinations and types of tourism that are being practiced;

c) launching a promotion campaign through the media and large travel agencies as well as expanding it via satellite channels.

To achieve these objectives, a charter flight support program was implemented to certain destinations in order to attract as many tourists as possible, a partnership with the major tourism agencies was signed to stimulate direct sales, was promoted through the public office from abroad of an international campaign on Egyptian tourism, the development of a website in 13 foreign languages, but also the development of new tourism segments such as desert, golf and therapeutical tourism.

Besides, the diversification of tourist products (hotels, safari tourism, yacht, ecolodge and accommodation units), infrastructure development in tourist centers and coastal areas was envisaged. For the year 2018 the Egyptian tourism ministry aims to increase the number of Spanish tourists around 100,000 visitors / year, as Spanish tourists reserve their vacations between 4 and 7 days (Daily News Egypt, 2017).

\section{Conclusions}

Geopolitical events largely influence the tourism industry as long as they persist for a long time, so the Egyptian president has set as its objective the fight against terrorism that has greatly affected the country over the last three years. If initially the terrorist actions were isolated shortly, they spread throughout the country with the establishment of the affiliated Islamic State party that first organized terrorist attacks in Sinai to create instability in the country's capital.

One of the causes of the multiplication of terrorist attacks is the increase in the number of terrorist group adherents but also political instability which, through the decisions made, make police and intelligence services increasingly static. Thus, European tourists for whom Egypt was the preferred destination today is easily avoided 
by tourists, which has led the Ministry of Tourism to implement more measures to promote domestic and international tourism and to help increase tourists' confidence.

In the coming years, Egypt must continue its counter-terrorism measures to fund illegal and organized crime. The results of the 2018 presidential election will mark the democratic or dictatorial future of the country in the context in which the actions of the current president are far from being in conformity with a democracy.

PICBE $\mid 669$

\section{References}

Alsharif, A., (2015, September 28). Egypt tourism industry expects moderate growth in 2015. Retrieved from https://www.reuters.com/article/us-egypt-tourism/egypttourism-industry-expects-moderate-growth-in-2015-idUSKCN0RS10F20150928

Africa Center for Strategic Studies . (2017, October 18). Al Shabaab Remains Virulent as ISIS Shifts to Egypt. Retrieved from https://africacenter.org/spotlight/al-shabaabremains-virulent-isis-shifts-egypt/

Central Agency for Public Mobilization and Statistics. (n.d.). Retrieved from http://www.capmas.gov.eg/Pages/IndicatorsPage.aspx?page_id=6133\&ind_id=22 51

Country Reports on Terrorism. United States Department of State Publication, Bureau of Counterterrorism.(2016).Retrieved from https://www.state.gov/j/ct/rls/crt/2016/272229.htm

Daily News Egypt. (2017, October 19). Retrieved from Tourism provides low-cost charter, charter-incentive programme for one year: https://dailynewsegypt.com/2017/10/19/tourism-provides-low-cost-chartercharter-incentive-programme-one-year/

Egypt Risk\&Compliance Report. (September 2017). Retrieved from https://docs.google.com/viewer?url=http://knowyourcountry.info/files/egyptam lreportaug2014_5.pdf

Global Terrorism Index. Institute for Economics\&Peace. (2017). Retrieved from https://reliefweb.int/sites/reliefweb.int/files/resources/Global\%20Terrorism\% 20Index\%202017\%20\%284\%29.pdf

International Narcotics Control Strategy Report.(2017).Retrieved from https://www.state.gov/j/inl/rls/nrcrpt/2017/

KPMG. (2017, March 1). Egypt - VAT introduced; new rules for settling tax disputes . Retrieved from https://home.kpmg.com/xx/en/home/insights/2017/02/egyptvat-introduced-new-rules-for-settling-tax-disputes.html

Messner, J., et al. (2017). Fragile State Index Annual Report. Washinghton, DC. Retrieved from http://fundforpeace.org/fsi/2017/05/14/fragile-states-index-2017-annualreport/951171705-fragile-states-index-annual-report-2017/

Morakabati, Y., Fletcher, J., \& Beavis, J. (2017). State of play: The impact of geopolitical events on international tourism in 2017. Travelzoo ITB Berlin.

Parkinson, J., \& Heyden, T. (2015, June 29). How terrorist attacks affect tourism. Retrieved from http://www.bbc.com/news/magazine-33310217

Rittichainuwat, B. N., \& Chakraborty, G. (2009). Perceived travel risks regarding terrorism and disease: The case of Thailand. Journal Tourism Management(30), 410-418.

Ryan, B., \& Sarah , L. (2013, July 10). 8 issues Egypt is facing. Retrieved from http://edition.cnn.com/2013/07/10/living/cnn-buzzfeed-what-egypt-isfighting-for/index.html 
Tahrir Institute for Middle East Policy. (2015, November 11). Egypt's rising security threat. Retrieved from https://timep.org/special-reports/egypts-rising-securitythreat/

Walsh, D., \& Youssef, N. (2017, November 28). Militants Kill 305 at Sufi Mosque in Egypt's Deadliest Terrorist Attack. Retrieved from https://www.nytimes.com/2017/11/24/world/middleeast/mosque-attackegypt.html

World Bank-Press release. (2017, December 5). Retrieved from World Bank Approves US\$1.15 billion Loan to Egypt to Boost Economy, Create Jobs:

http://www.worldbank.org/en/news/press-release/2017/12/05/world-bankapproves-us115-billion-loan-to-egypt-to-boost-economy-create-jobs 